Columbia Law School

Scholarship Archive

Making Sense of the Arbitrator's Ruling in DS 316 EC and Certain Member States - Measures Affecting Trade in Large Civil Aircraft (Article 22.6-EC): A Jigsaw Puzzle with (at Least) a Couple

\title{
Missing Pieces
}

Petros C. Mavroidis

Columbia Law School, petros.mavroidis@unine.ch

Kamal Saggi

Vanderbilt University College of Arts and Science, k.saggi@vanderbilt.edu

Follow this and additional works at: https://scholarship.law.columbia.edu/faculty_scholarship

Part of the Dispute Resolution and Arbitration Commons, International Law Commons, International Trade Law Commons, Securities Law Commons, and the Transnational Law Commons

\section{Recommended Citation}

Petros C. Mavroidis \& Kamal Saggi, Making Sense of the Arbitrator's Ruling in DS 316 EC and Certain Member States - Measures Affecting Trade in Large Civil Aircraft (Article 22.6-EC): A Jigsaw Puzzle with (at Least) a Couple Missing Pieces, EUROPEAN UnIVERSITY INSTITUTE, ROBERT SCHUMAN CENTRE FOR AdVANCED Studies, Global Governance Programme Working Paper No. RSCAS 2020/44 (2020).

Available at: https://scholarship.law.columbia.edu/faculty_scholarship/2693

This Working Paper is brought to you for free and open access by the Faculty Publications at Scholarship Archive. It has been accepted for inclusion in Faculty Scholarship by an authorized administrator of Scholarship Archive. For more information, please contact scholarshiparchive@law.columbia.edu. 

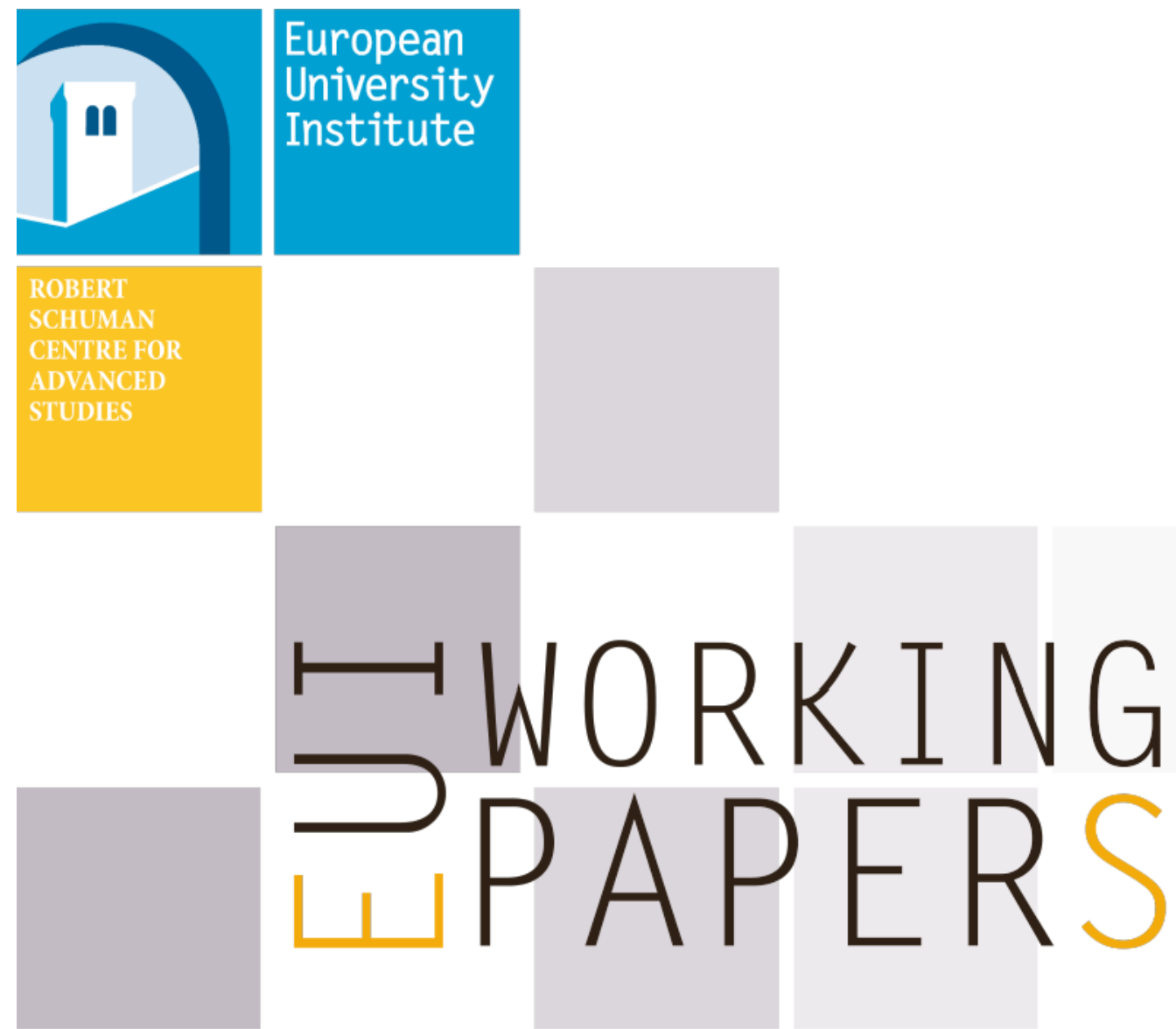

RSCAS 2020/44

Robert Schuman Centre for Advanced Studies Global Governance Programme-405

Making Sense of the Arbitrator's Ruling in DS 316 EC and Certain Member States- Measures Affecting Trade in Large Civil Aircraft (Article 22.6-EC) A Jigsaw Puzzle with (at Least) a Couple Missing Pieces

Petros C. Mavroidis and Kamal Saggi 
European University Institute

Robert Schuman Centre for Advanced Studies

Global Governance Programme

Making Sense of the Arbitrator's Ruling in

DS 316 EC and Certain Member States- Measures Affecting Trade in Large Civil Aircraft (Article 22.6-EC)

A Jigsaw Puzzle with (at Least) a Couple Missing Pieces

Petros C. Mavroidis and Kamal Saggi

EUI Working Paper RSCAS 2020/44 
Terms of access and reuse for this work are governed by the Creative Commons Attribution 4.0 (CCBY 4.0) International license. If cited or quoted, reference should be made to the full name of the author(s), editor(s), the title, the working paper series and number, the year and the publisher.

ISSN 1028-3625

(C) Petros C. Mavroidis and Kamal Saggi, 2020

This work is licensed under a Creative Commons Attribution 4.0 (CC-BY 4.0) International license. https://creativecommons.org/licenses/by/4.0/

Published in July 2020 by the European University Institute.

Badia Fiesolana, via dei Roccettini 9

I - 50014 San Domenico di Fiesole (FI)

Italy

Views expressed in this publication reflect the opinion of individual author(s) and not those of the European University Institute.

This publication is available in Open Access in Cadmus, the EUI Research Repository:

https://cadmus.eui.eu 


\section{Robert Schuman Centre for Advanced Studies}

The Robert Schuman Centre for Advanced Studies, created in 1992 and currently directed by Professor Brigid Laffan, aims to develop inter-disciplinary and comparative research on the major issues facing the process of European integration, European societies and Europe's place in $21^{\text {st }}$ century global politics.

The Centre is home to a large post-doctoral programme and hosts major research programmes, projects and data sets, in addition to a range of working groups and ad hoc initiatives. The research agenda is organised around a set of core themes and is continuously evolving, reflecting the changing agenda of European integration, the expanding membership of the European Union, developments in Europe's neighbourhood and the wider world.

For more information: http://eui.eu/rscas

The EUI and the RSCAS are not responsible for the opinion expressed by the author(s).

\section{The Global Governance Programme}

The Global Governance Programme is one of the flagship programmes of the Robert Schuman Centre. It is a community of outstanding professors and scholars that produces high quality research and engages with the world of practice through policy dialogue. Established and early-career scholars work on issues of global governance within and beyond academia, focusing on four broad and interdisciplinary areas: Global Economics, Europe in the World, Cultural Pluralism and Global Citizenship.

The Programme also aims to contribute to the fostering of present and future generations of policy and decision makers through its executive training programme: the Academy of Global Governance, where theory and 'real world' experience meet and where leading academics, top-level officials, heads of international organisations and senior executives discuss on topical issues relating to global governance.

For more information: http://globalgovernanceprogramme.eui.eu

The European University Institute and the Robert Schuman Centre are not responsible for the opinions expressed by the author(s). 


\begin{abstract}
"The U.S. won a \$7.5 Billion award from the World Trade Organization against the European Union, who has for many years treated the USA very badly on Trade due to Tariffs, Trade Barriers, and more. This case going on for years, a nice victory", tweeted President Trump's on October 3, 2019. The United States (US) won not only the highest amount of retaliation ever adjudicated in the history of the WTO but also an ongoing right to retaliate on an annual basis until such time as the EU had complied by either removing the subsidies it granted Airbus or somehow neutralizing their adverse effects on Boeing. In light of the facts of the case, this ruling has two major shortcomings. First, in sharp contrast with the statutory language and practice until now, the Arbitrator effectively introduced a permanent liability rule into the WTO system through the backdoor. Second, given the way the decision and the associated award is written, it is simply impossible for the EU to comply because (a) the contested subsidies are no longer in existence and (b) no guidance has been provided on how the EU might go about removing their effects if it sought to achieve compliance. Thus, in all likelihood, the EU is saddled with a ruling that obligates it to cough up an annual sum of $\$ 7.5$ billion USD for an indefinite time period.
\end{abstract}

\title{
Keywords
}

Airbus; Retaliation; WTO

JEL Classification: K40 


\section{The Gloves Are Finally Off (After Years of Empty Threats) *}

Airbus and Boeing have been, and continue to be, a duopoly in wide bodied aircrafts ever since Airbus entered the market on the basis of generous subsidies provided by several European nations. Their fleet extends to other aircrafts as well, and, over the years, they have been subjected to competition by Embraer and Bombardier (now part of the Airbus family) for short-haul planes. All four producers have received generous subsidies over the years, and, probably counter-intuitively so, have engaged in litigation concerning these subsidies at the WTO.

Although the Airbus-Boeing saga is fifteen years old its first tangible legal outcome saw the light of day only recently: the Arbitrator awarded the US an authorization to retaliate for the unprecedented amount of almost $\$ 7.5$ billion, which it can impose annually, until the European Union (EU) has withdrawn subsidies it provided Airbus and/or removed all of their adverse effects on Boeing.

Somewhat predictably, the EU reacted vehemently to this unprecedented level of retaliation and noted that the formal report of the Arbitrator raised some "serious concerns". Canada made sympathetic comments to the EU position, whereas the US delegation, in a measured statement, expressed the hope that the Arbitrator's ${ }^{1}$ award would induce the EU to abandon its subsidy program. ${ }^{2}$ Given the economic realities of this market, it is doubtful that the EU will or can do so. Building on the theoretical foundation provided by Brander and Spencer (1985), Krugman (1995) argued persuasively that in an industry like aircraft manufacturing, subsidizing (assuming relatively inelastic demand, a rather realistic assumption) can have positive effects for the subsidizer, and even the world as a whole (despite hurting the competitor). Irwin and Pavcnik (2004) have added to positive welfare implications for consumers by pointing to technology effects that can spill across products (such as improved safety), an outcome of special relevance in a concentrated market where the two dominant firms produce multiple related products.

The Arbitrator's report was issued in October 2019 and a brief summary of the key legal developments is as follows:

- The original panel report circulated on June 30, 2010 found that EU subsidies in the form of "launch aid", "infrastructure", "equity infusions", and "R\&D" were in violation of the Agreement on Subsidies and Countervailing Measures (SCM). The panel asked the EU to comply with its findings within 90 days for those subsidies that it had found to be prohibited, and within 180 days for the remaining (actionable) subsidies;

- Following an appeal, the Appellate Body (AB) modified some of the panel's findings (those regarding export subsidies), but still held, in its report of June 1, 2011, that the EU should remove the adverse effects of its subsidies, or withdraw the subsidies altogether within 180 days; ${ }^{3}$

- The parties to the dispute disagreed with respect to the adequacy of the subsequent implementing efforts by the EU. A very lengthy process before the compliance panel was the next step of the saga, and on September 22, 2016, the panel concluded that implementation had not occurred. It added that the launch aid granted for the new A350xx model was also not in compliance with the EU's obligations;

- On May 18, 2018, the AB issued its report, following an appeal (and a cross-appeal to this effect), and essentially confirmed the key findings of the compliance panel;

For helpful comments, we would like to thank Henrik Horn, Doug Irwin, Kirtikumar Mehta, and Damien J. Neven.

1 The DSU clarifies that the term “Arbitrator" refers to the original panel, if possible. Arbitrator's awards cannot be appealed.

2 EEAS (European External Action Service), Geneva, 14 October 2019, EU Statement at the Special DSB Meeting. All three countries' reactions are available at www.wto.org/english/res_/webcas_e/rss_e.htm.

3 Hahn and Mehta (2013) provide a detailed discussion of the process up to this point. 
- Following the issuance of the AB's report, the US proposed a list of countermeasures. The EU objected, arguing that the level proposed by the US was excessive, and the present Arbitrator's Decision, issued on October 2, 2019, is the outcome of this request $;^{4}$

- In the meantime, the EU tabled a request for a second compliance panel, arguing that new measures it had taken were adequate to ensure compliance on its part. This second panel had not even managed to wrap up its work by the time the Arbitrator issued its Decision. In other words, the Arbitrator's ruling occurred before the second panel had even verified whether or not the EU's claim regarding compliance was correct. Thus, the US, was authorized to retaliate on October 2, 2019, and only two months later, on December 2, 2019, did the world learn that the EU had not complied with the findings of the original panel/AB. This report could be appealed, but, in light of today's crisis surrounding the future of the $\mathrm{AB}$, the fate of such an appeal is unclear.

The Arbitrator's Decision raises a number of significant issues, both legal and economic. We briefly recap the relevant case law in Section 2. Then, in Section 3, we provide the facts of the case, and discuss the Arbitrator's award. In Section 4, we explain why we disagree with the Arbitrator's decision. Section 5 recaps our main findings and lays out a path for future work.

\section{Past Case-Law}

Even though there is no binding precedent in WTO, past decisions offer guidance and shape the expectations of the membership.

\subsection{Mandate of Arbitrators: Get a Number, Follow Procedures}

The statutory language detailing the Arbitrator's task is set out in Article 22.7 of DSU. In short, the Arbitrator must follow the procedure contained in Article 22.3 and ensure the level of retaliation does not exceed the amount of injury caused (Article 22.4).

Article 22.1 reflects the statutory preference for "property rules", e.g., performance of the contract. "Liability rules" (compensation ${ }^{5}$ or retaliation) are transitional in the sense that they remain in force only until implementation has occurred. The Arbitrator in EC-Bananas III (Article 22.6-EC) held that the purpose of retaliation is to induce compliance (\$6.3). It cannot though, in the name of inducing compliance run afoul of Article 22.4 of DSU. When it comes to calculating the level of retaliation, its Article 22.4 of DSU, and not its potential persuasive effect to implement, that matters. ${ }^{6}$

Article 22.3 provides for a sequence to be followed, whereby the retaliating state must first try to retaliate in the same sector, then in the same agreement, and then, if necessary, in a different agreement ("cross-retaliation"). It can move up to a different sector/agreement, "if that party considers that it is not practicable or effective" to retaliate in the same sector/agreement. As Anderson (2002), one of the Arbitrators in this case explained, the review of compliance with Article 22.3 was rather minimal. It makes sense because of a clear precedent: in US-COOL (Article 22.6-US), ${ }^{7}$ the Arbitrators came up

4 The parties to the dispute had agreed to a sequencing agreement, see WTO Doc. WT/316/21 of January 17, 2012, which in relevant part reads: "As the matter has been referred to arbitration, the United States and the EU shall request the arbitrator to suspend that proceeding."

5 The form of compensation is not prejudged. It happened only once in a case involving inadequate enforcement of intellectual property rights, see Grossman and Mavroidis (2007), and Limão and Saggi (2008).

6 There is one exception to this rule: in Canada-Aircraft Credits and Guarantees (Article 22.6-Canada), without stating that they were suggesting punitive damages, the Arbitrators revised their authorized level upwards by adding a $20 \%$ mark-up, because Canada had officially stated that it would maintain its subsidy programme irrespective of the Arbitrators' decision (§ 3.49).

7 Mavroidis and Saggi (2014), and Bown and Brewster (2017) discuss this case. 
with a comprehensive formulation to this effect, which, with very minor changes (mostly, of linguistic nature) has been reproduced in every report ever since.

\subsection{Allocation of Burden of Proof}

Case law has established that it is the party questioning the level of retaliation presented by the injured party that carries the burden of making a prima facie case that the proposed level of retaliation is inapposite. [US-COOL (Article 22.6-US), $\S \S 4.7$ et seq.]. The disputing party cannot simply propose an alternative level; it must show why the proposed calculation is wrong ( $\$ 4.12$ et seq.).

\subsection{Constructing the Counterfactual}

In order to establish the level of damages (and, thus, of permissible retaliation), the Arbitrator usually constructs a counterfactual and compares the actual state of affairs to a world without the challenged measure. This process has been followed in the majority of disputes that require such an evaluation. ${ }^{8}$ The question, of course, is what should the counterfactual be? The DSU is silent on this score. The natural candidate, of course, is a world without the challenged measure. In other words, the challenge is to determine what would have transpired had the challenged measure(s) not been adopted and then use that to determine the appropriate remedy. If the measure has expired (e.g., it is non-recurring) then the total damage should be capped at the level observed. If the measure is still in place (e.g., it is recurring), then the Arbitrator needs to decide on the level of permissible retaliation. To do so, they could use information from a reliable (e.g., not suffering from sample bias) reference period to establish the level of injury during that period, and then adjust it appropriately to establish the proper amount of injury (and thus, retaliation) suffered over the full duration over which the measure is deemed to have adverse effects. ${ }^{9}$

\subsection{No Retroactivity}

In previous disputes that have involved arbitration, the Arbitrators have consistently recommended prospective remedies. The obligation to compensate the injured party kicks in from the end of the reasonable period of time granted to achieve compliance. ${ }^{10}$

\subsection{Indirect Benefits Excluded}

In EC-Bananas III (United States) (Article 22.6-EC), the US had claimed that by blocking imports of bananas originating in Mexico into its market, the EU was ipso facto blocking exports of US inputs (such as fertilizers) used in the production of Mexican bananas and that it should be compensated for lost profits. The Arbitrator decided against the US claim in this respect and ruled that the EU could be held liable to retaliation only for trade in bananas lost by Mexican exporters and not for trade in fertilizers lost by US exporters ( $\S 6.12-14)$.

8 In Balistreri et al. (2020), we provide the list of all cases where no counterfactual was constructed.

9 Comparing it with any other, even "reasonable" measure suffers from two vices: first, such measure has not been adopted during the reasonable period of time; second, the Arbitrator will be prejudging its legality, even though it has no mandate to do so. In Balistreri et al. (2020), we mention the four cases where it happened: US-Section 110(5) Copyright Act; ECBananas III (Article 22.6-EC); US-Gambling (Article 22.6-US); and US-Washing Machines (Article 22.6-US).

10 EC-Hormones (US) (Article 22.6-EC), (§38), provides a typical illustration. 


\subsection{Sequencing}

By sequencing, we understand that a request for authorization to retaliate should follow the issuance of a compliance panel and/or $\mathrm{AB}$ report. This seems to be quite natural, otherwise, an authorization could be issued, and then a panel (and/or the $\mathrm{AB}$ ) might later find that compliance had occurred. But then, this would be contra legem, as request for authorization can take place only if implementation has not occurred. And yet, in EC-Bananas III (Article 22.6-EC) the opposite actually happened: a request for authorization was granted three days before the compliance panel had decided that implementation had not occurred. The Arbitrators based themselves in the wording of Article 22.6 of DSU, which calls for them to decide on authorization within thirty days from the expiry of the reasonable period of time (RPT). This wording refers to the case where there is agreement that no implementation has occurred. If there is no agreement, as per the unambiguous wording of Article 21.5 of DSU, a compliance panel must be established. This is so because the overarching discipline in the DSU is Article 23.2 of the DSU, which requests that all disputes be submitted to third-party adjudication. ${ }^{11}$ Following this incident, the membership has de facto always observed sequencing.

\section{So What Happened Here?}

The Arbitrators award consists of two key elements:

- First, the US was authorized to implement an annual retaliation of $\$ 7,496.623 .000$

- Second, this retaliation could take the form of tariff concessions and/or suspension of horizontal or sectoral commitments in the realm of services trade.

Since the US has not cross-retaliated, we will concentrate on first point. ${ }^{12}$

\subsection{The Subsidies Involved}

The US had challenged the consistency of Launch Aid programs, agreements between member States of the EU and Airbus, in the form of MoUs (memoranda of understanding, some of them dating as far back as 1969), and other infusions (described in pp. 365 et seq. of the original panel report, DS316, and pp. 94 et seq., of the compliance panel report, DS316/RW), namely:

- A launch aid program, which took place between 1969-2006, and helped launch a few Airbus models ("LA/MSF", launch aid, member state financing);

- Equity infusions by Germany and France for a period partially overlapping with the abovementioned period;

- Infrastructure-related projects aiming to provide facilities for Airbus undertaken during the 1980s;

- R\&D (research and development) subsidies that also occurred during more or less the same time.

The $\mathrm{AB}$ modified the compliance panel's findings regarding the non-LA/MSF subsidies. Both the adverse effects that were determined to exist by the AB ('significant lost sales', and 'impedance') were found to have been caused solely by the two LA/MSF subsidies (A380 LA/MSF, and A350 LA/MSF) alone [EC - Large Civil Aircraft (Article 21.5 - US), §§5.412, 5.761, 5.768, and 5.775, 6.31(a), 6.37(a), 6.42(a); see also $\$ 4.12$ of the Arbitral Award EC - Large Civil Aircraft (Article 22.6-EC)]. Thus, in what follows we restrict our analysis to the effects of launch aid subsidies granted to Airbus for the A380 and A350 planes.

\footnotetext{
11 Mavroidis (2016).

${ }^{12} \mathrm{https} / / /$ ustr.gov/sites/default/files/enforcement/301Investigations/Review_of_Action_Enforcement_of_U.S._WTO_Rights_ in_Large_Civil_Aircraft_Dispute.pdf.
} 


\subsection{The US Request}

The US demonstration of adverse effects consists in showing that, over the relevant time period, because of launch aid Airbus sold 47 planes to major airlines. As per the US view, which the Arbitrator endorsed, those 47 planes would have been sold by Boeing had launch aid not been granted to Airbus. In other words, the granting of launch aid created a viable competitor for Boeing (in the form of Airbus) which subsequently took away sales from Boeing.

In the US view, these cases of lost sales and/or impedance concerned six geographic markets (Australia, China, European Union, Korea, Singapore, and the United Arab Emirates), where Airbus sold 47 A380s and Boeing only ten units. The US view is that had it not been for the "product effects" of the A380 LA/MSF, Boeing would have delivered an equal number of its closest competing model in the counterfactual (i.e. 47 Boeing 747-8Is). It follows then that the value of impedance under this view would be the average net Boeing price multiplied by the number of units the sale of which had been impeded ( $\$ 6.359$ of the report). Based on this calculation, the US requested the right to retaliate on an annual basis.

The EU objected, claiming that these eleven instances could not serve as benchmark for annual suspension as they involved non-recurring subsidies. More concretely, the EU made two points to substantiate its claim. ${ }^{13}$ First, there are no findings by any WTO court pertaining to this case that provide evidence of adverse effects to the United States after 2013. Second, it had already been decided that the production of A380, one of the Airbus models that had benefitted from subsidies during the reference period, would be discontinued. In fact, at the moment when the Arbitrator had been requested to pronounce on the level of permissible retaliation, the production of A380 had already stopped. ${ }^{14}$

\subsection{The Award}

In what follows, we do not discuss all relevant details of the Arbitrator's judgment and focus instead on only its key points.

\subsubsection{The Permissible Level of Retaliation}

The Arbitrator estimated the damage from lost Boeing sales to be at $\$ 7,496.623 .000$. It then, in a somewhat cryptic passage, authorized the US to retaliate up to this level on annual basis until the EU had complied with the award (\$6.52):

The European Union argues that Annual Suspension has so far only been granted in arbitrations addressing "recurring" measures. The European Union has not defined this term. Presumably, the European Union was using the term in a broad sense to refer to measures that would be expected to produce relevant effects on an ongoing basis. As we see it, however, "recurrence" of a measure found to be WTO-inconsistent, however one defines that concept, is not a prerequisite to granting Annual Suspension. Countermeasures serve to induce compliance in respect of all manner of measures found to be WTO-inconsistent, whether they are "recurring" or "non-recurring". Until and unless substantive compliance has been achieved and is multilaterally confirmed or a mutually agreed solution has been reached, there remains a valid rationale for granting Annual Suspension and maintaining it at the authorized level.

13 The Arbitrator observed that the EU lawyers did not elaborate on the meaning of non-recurring subsidies. Because of the principle jura novit curia (the court knows the law), this reaction is unwarranted. There is voluminous case law on this issue, which we discussed in Grossman and Mavroidis (2007a).

14 In $\$ \$ 6.227$ et seq., the Arbitrator acknowledged that cancellations of orders for A380s had already taken place even before the decision to cancel the production of this model. Actually, it is very likely that cancellations of orders led to cancellation of production. 
It appears to us that the Arbitrator almost seems to be justifying the annual nature of the suspension to "induce" compliance on the part of the EU, as opposed to making the US whole in terms of the damage it suffered from the EU's subsidies to Airbus. This perspective raises fundamental questions about the intended purpose of retaliation. If the primary goal of authorizing retaliation is to induce compliance, one could easily justify awards far in excess of damages suffered. But, on the other hand, if the primary purpose is to compensate the injured party, it is crucial that the level of the suspension authorized be tied as closely as possible to the actual damage suffered or is reasonably expected to be suffered in case the measure cannot be removed or is determined to have long-lasting effects.

\title{
3.3.2 What is the Appropriate Counterfactual?
}

The Arbitrator accepted that the US counterfactual (each Airbus sold would have been replaced by a Boeing) was the appropriate counterfactual ( $\$ 6.199$ et seq., the number of Airbus sold that impeded sales of Boeings, §6.358). The level of adjudicated retaliation rights $(\$ 7,496.623 .000)$, corresponds to lost or impeded sales of wide-body planes, 47 in total during the period 2011-2013.

\subsubsection{Retroactivity?}

Retaliation starts from the end of the RPT available to EU to achieve compliance. In this case it was December 2011, as we explain later. The reference period, which the Arbitrators used, was December 2011-December 2013. Impedance during that period concerns deliveries of A380, a model the production of which had been discontinued by the time the Arbitrators had been asked to pronounce on the EU objection to the US request for authorization.

\subsubsection{No Interest Rate Required}

The US requested adjustment for inflation, as the reference period ended in December 2013, and substantial time had passed since that date. The Arbitrator noted that only one Arbitrator had done so in the past, and without much explanation, rejected the US request (\$\$6.515-522).

\subsubsection{Value Added}

The issue of value added, which had been hinted at but not addressed comprehensively before, was dealt with in $\$ 6.145$ of the report:

\begin{abstract}
...the European Union's argument hinges on the notion that it is improper to include in the assessment of the maximum level of countermeasures the value of a Boeing LCA that is not attributable to US inputs. Taken to its logical end, this argument would have the United States trace the value of Boeing LCA back through the supply chain to the level of raw materials and ascertain the source of each of the hundreds of components, as we could apportion countermeasures to the United States only insofar as it was the source of such inputs. This would make the exercise of calculating the level of countermeasures "time consuming and exceedingly complicated", as the European Union itself notes. We have difficulty squaring this argument with the expeditious nature of Article 22.6 arbitration proceedings, especially in the light of the fact that LCA production is not unique in relying on complex and dynamically optimized international supply chains.
\end{abstract}

Thus, for reasons of administrative facility, the Arbitrator rejected the EU's request to base the award on the value-added of Boeing as opposed to the value of lost sales.

\subsection{Improper Sequencing}

The Decision by the Arbitrator was issued on October 2, 2019. In the meantime, the EU had requested a second compliance panel to be established. At the moment of the issuance of the Arbitrators' Decision, 
it was uncertain whether the second compliance report would have found the EU to be in compliance or not. The second compliance report was issued on December 2, 2019. Consequently, by not observing sequencing this time, the Arbitrator authorized the US to retaliate, while uncertainty as to the adequacy of EU implementation was still looming.

\section{Discussion}

This award is a significant departure from prior practice. What is worse, it is puzzling and potentially incorrect in several respects.

\subsection{The Subsidies in Place}

To properly evaluate this case, we first need to identify the subsidies that were taken into account when quantifying retaliation rights. This might sound trivial but it actually cuts to the heart of the matter. The Arbitrator decided that two separate $\mathrm{LA} / \mathrm{MSF}^{15}$ subsidy schemes applicable to two specific planes (AX350XWB and A380XWB) had not been removed and were inconsistent with the EU's obligations.

The Arbitrator, on the other hand, had to observe Article 7.10 of SCM which states:

In the event that a party to the dispute requests arbitration under paragraph 6 of Article 22 of the DSU, the Arbitrator shall determine whether the countermeasures are commensurate with the degree and nature of the adverse effects determined to exist. (emphasis added)

In the present case, the term "determined to exist" can only refer to the period before June 2011, when the original panel/AB report had been issued. The EU had six months (as per Article 7.9 of SCM) to remove the effects of the subsidies determined to exist. This period ended in December 2011. And yet the compliance panel/AB chose a reference period of December 2011-December 2013. The compliance panel explained ( $\$ 6.85$ et seq.) that this reference period served to examine the impact of adverse effects of LA/MSF.

Under Article 7.9 of SCM, a party granting an actionable subsidy must either withdraw the scheme or remove its effects. In $\$ 5.383$, the compliance $\mathrm{AB}$ report clarified that the obligation to remove exists only if a subsidy continues to be granted. So the question is, did both A380XWB and A350XWB LA/MSF continue to exist at the end of the RPT? And here lies the first grave error of the Arbitrator because LA/MSF for A350XWB did not even exist when the original panel report was issued. Indeed, in $\$ 7.314$, the original panel report dismissed the US argument to this effect. In similar vein, the compliance AB report in \$5.597, affirmed that these were new subsidies, that is, subsidies that were not being granted when the original panel had issued its findings.

And yet, these subsidies (LA/MSF for A350XWB) somehow found their way before the Arbitrator perhaps because of their close nexus to subsidies that were being granted throughout the RPT, that is subsidies (LA/MSF) granted for other types of planes. Now, a compliance panel does not examine anymore the original measure. Rather, it reviews the adequacy of a new measure adopted to achieve compliance, and asks if it has led to compliance or not. But one might ask: how can the granting of new subsidies be considered as a measure taken in order to achieve compliance, when the very wording of Article 7.9 calls for either withdrawal or the removal of effects of previously bestowed subsidies? In which of the two categories does the LA/MSF for A350XWB fall? "In neither", is the short answer. The

15 Even this term was a compromise. EU did not share the view that its schemes qualified as launch aid (LA), and proposed MSF (member state financing) instead. WTO courts struck a compromise, WT/DS316/ R at \$7.291. Our work has been severely hampered by the fact that nowhere has the panel/AB/arbitrator reproduced an adequate description of the LA/MSF, which were considered confidential documents in their entirety and were not included in the published report. There is some description in $\S \S 7.290$ et seq. of the original report, which is ... well, far from adequate for anyone to understand the exact function of LA/MSF. This is quite an omission, since a lot of the analysis in the arbitrator's reports hinges on the effects of LA/MSF a few years after they had been granted. 
LA/MSF for A350XWB is neither withdrawal of subsidies sanctioned by the original panel, nor a measure aimed at removing their effects. It is essentially a new subsidy.

Thus, in our view, the Arbitrator's report erred by including LA/MSF for A350WXB in its ruling. And the error could potentially be even greater since it is not even clear that LA/MSF for the A380WWB was even within the terms of reference. We quote from the compliance AB report, §5.596:

We note that, while contending that the pre-A380 LA/MSF subsidies "ceased to exist" before the implementation period and were therefore not within the scope of its compliance obligation, the European Union does not dispute that the A380 LA/MSF subsidies continued to exist during the post-implementation period. (emphasis added)

Talk about Pythic oracles. What are these pre-A380 subsidies, and in what don they differ from the A380 subsidies? Did the EU really argue that subsidies somehow re-appeared after they had "ceased to exist"? Can that ever be the case? Alas, we cannot speculate more on this issue, as we lack information regarding the exact parameters of each LA/MSF, as discussed. We will thus, follow the logic of the Arbitrator, that is, that LS/MSF for A380XWB continued to produce effects after the RPT.

\subsection{Is the Level of Permissible Retaliation Correct?}

Recall that the Arbitrator awarded the US retaliation rights up to $\$ 7,496.623 .000$ that can be imposed annually, until implementation occurs.

\subsubsection{Quantifying the Damage Suffered and Annualization}

The Arbitrator's finding can only rest on the following presumptions:

- LA/MSF for A350XWB and A380XWB had not been withdrawn; and

- These subsidies continue to produce essentially permanent effects that needed to be removed to achieve compliance.

Let us start with the quantification of effects, assuming that the two LA/MSF schemes are still in place. All the US argued in terms of effects was that Boeing lost sales of 47 planes. Furthermore, the US had quantified the damage resulting from these lost sales at \$7,496.623.000. Well, then, since it was game, set and match US, why did not the Arbitrator limit the amount of rights to this number? Every additional cent authorized undoes, ipso facto, the legislative imperative of Article 22.4 which is the strict equality between damage inflicted and the level of retaliation authorized. To add insult to injury (for the EU), the production of A380 had been cancelled in the meantime and the Arbitrator was well aware of this fact.

An annual level of retaliation in principle translates into an almost infinite level of permissible compensation, especially in an era of near-zero (and even negative) interest rates. In our view, the Arbitrator seriously overshot the amount of permissible retaliation that could and should have been granted in this case. Furthermore, the Arbitrator noted:

This suggests to us that the maximum permissible duration of countermeasures is controlled not by the ongoing effects of a measure that was found to be WTO-inconsistent, but by the responding party's compliance status. The Appellate Body has indicated that this aspect of Annual Suspension, i.e. that it may remain in force pending confirmation of a responding party's substantive compliance, is consistent with the object and purpose of the DSU.

(\$6.49).

This is a fairly serious misquotation of case law. The $\mathrm{AB}$ indeed said as much, but not without taking into account Article 22.4. Yes, retaliation can stay in place until compliance is achieved. But not, any retaliation: only lawful retaliation, that is, retaliation which observes Article 22.4 (i.e. that which does not exceed the damage inflicted). Illegal retaliation, like the one presently sanctioned by the Arbitrator, 
which grossly exceeds this amount cannot be awarded in the first place let alone be allowed to stay in place until compliance has been achieved.

\subsubsection{How much did Boeing lose?}

The Arbitrator took it for granted that had companies not bought Airbuses, they would have bought Boeings instead. But how many Boeings would have been sold? And at what price? The Arbitrator essentially took the price of Boeings and multiplied it with the number of planes sold by Airbus over the relevant time period to determine the damage suffered by Boeing. But this logic ignores the fact that if Boeing did not face competition from Airbus, both its price and its sales would be different. Simply put, the equilibrium price and sales under a monopolistic market structure will almost never be the same as that of a duopoly.

Economic theory shows that, assuming no cartelization, market price under duopoly is typically lower that under monopoly whereas total output sold is higher since the monopolist restricts sales to maximize profits whereas duopolists compete to steal market share from one another thereby producing a higher level of collective output. The key implication of this for the present case is that in the absence of competition from Airbus, Boeing would have charged a higher price for its planes and sold fewer units of them. In other words, it is incorrect to simply assume, as was done by the US and then also by the Arbitrator, that Boeing would have sold exactly 47 planes in the absence of launch aid granted to Airbus and sold them at the same price that was observed in the market after Airbus entered. Furthermore, the loss suffered by Boeing over the relevant time period would be higher than the amount authorized by the Arbitrator since its profit in the absence of competition from Airbus would have been higher.

The above argument is illustrated in Figure 1 which shows strategic competition between two firms (labelled firm 1 and 2) and compares it with the monopoly outcome.

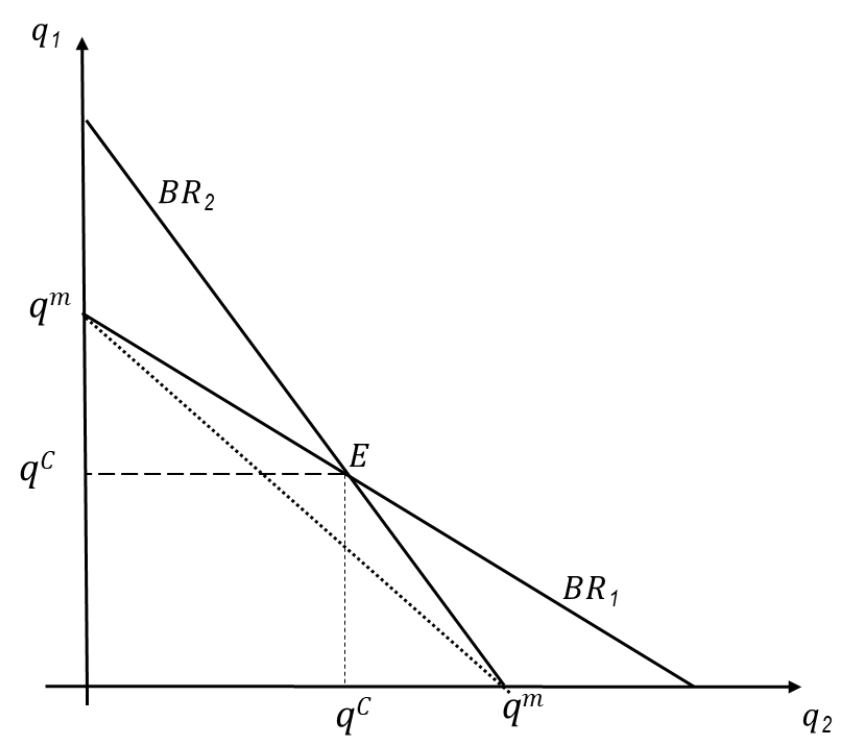

Figure 1: Cournot-Nash Competition in a Symmetric Duopoly

The figure captures the Nash equilibrium outcome of Cournot competition in a duopoly wherein each firm chooses its output level taking the output of its rival into account. The downward sloping line $B R_{I}$ is the best response of firm 1 to various levels of output chosen by its rival (i.e. firm 2) while $B R_{2}$ is the best response of firm 2 to alternative output levels of firm 1 . These best response curves are downward 
sloping because each firm finds it optimal to cut back on its own output when its rival increases its output. Intuitively, all else equal, an increase in one firm's output implies a lower market price thereby providing the other firm an incentive to cut back its output.

The intersection of the two best response curves $\left(B R_{l}\right.$ and $\left.B R_{2}\right)$ gives the Cournot-Nash Equilibrium at point $E$. This equilibrium point describes a situation where the output level chosen by each firm maximizes its own profit given what its rival is producing, so that neither firm has a unilateral incentive to alter its output. But this does not mean that the firms would not benefit from collectively altering their output levels. For example, if they could collude with impunity they would choose to produce a total level of output equal to that of the monopolist, potentially splitting monopoly profits between themselves. In Figure 1, the combined output of the two firms along the downward sloping dashed line equals the monopoly output $q^{m}$. Observe that the total output under the Cournot Nash Equilibrium (which equals $2 q^{C}$ ) exceeds monopoly output $q^{m}$ since the equilibrium point $E$ lies above the dashed line along which total industry output equals $q^{m}$.

In the context of the present case, the Arbitrator accepted the US claim that the loss suffered by Boeing under duopoly competition with Airbus should be calculated as follows:

(Price of Boeing when competing with subsidized Airbus) $\mathrm{x}$ (volume of units impeded or not sold)

But is this an incorrect measurement of the damage to Boeing. Rather, Boeing's loss equals the reduction in its profits caused by the subsidy:

Boeing Profit (no subsidies) - Boeing Profit (subsidies)

Clearly, this is conceptually and practically distinct from the level awarded by the Arbitrator since one can reasonably argue that, absent the subsidies, Boeing would essentially have been a monopolist in the market.

\subsubsection{Value Added}

We have cited $\S 6.145$ of the report, where the Arbitrator, for reasons of administrative facility closed the door to retaliation being limited to value-added only. The problem with this approach is the potential for over-compensation: most modern manufactured goods, especially aircraft, utilize a complex global value chain so that the value of imported intermediates used by Boeing should in principle be subtracted from its export revenue and its damage ought to be based on its own value-added lost to Airbus due to the displacement of its sales. Indeed, Anderson (2002), one of the Arbitrators in the bananas saga, warned against the danger of this type of over-compensation. He explained why, with the advent of GVCs (global value chains), and the increasing outsourcing of intermediate goods, ${ }^{16}$ there is a real risk of over-compensating when awards are based only on the value of final goods trade lost due to a measure. This aspect of the case draws attention to the larger issue of the surveillance of arbitration awards.

It could be that, facing a recalcitrant European Union, Boeing cancels imports of inputs, while the US administration continues profiting from countermeasures the level of which includes the value of cancelled items. ${ }^{17}$

\subsubsection{No Interest?}

Because of the time passage between the end of the reference period and the time of the issuance of the award, the US requested adjustment for inflation. Without explaining much, the Arbitrators refused to concede this request ( $\S 6.515$ et seq.).

16 Feenstra (1998).

17 This will depend on contractual arrangements between Boeing and its suppliers, of course. 
The problem with the award on this point is anyway, the absence of explanation why no adjustment for the passage of time was made. To us, the US request on this front seems quite legitimate.

\subsection{Can the EU Ever Comply?}

In principle, the EU has two routes to compliance: either remove the measures at stake (i.e. the launch aid subsidies) or remove their adverse effects on Boeing. Consider first the removal of subsidies. How can the EU remove these subsidies when it was not even producing A380 as of 2021? Furthermore, it does not bestow A350XWB with an LA/MSF either. So, there is essentially nothing left to withdraw. Now consider the second route to compliance: i.e. the EU attempts to remove the effects of past subsidies. Apparently, over the relevant time period under consideration in this dispute, the effects of this subsidies were exhausted in the sales of the 47 Airbuses but somehow the US won the right to retaliate forever (unless, of course, the trans-Atlantic partners strike a deal under which the US agrees to suspend its retaliation).

Thus, the most profound problem afflicting the Arbitrator's decision is that the retaliation granted per se can never hope to induce compliance for the simple reason that compliance in the present case is simply unachievable. If the effects of the subsidies at stake were already exhausted by the time of the ruling, there is nothing left to remove. But if the argument is that these effects were still in play (and likely to remain so during the future), what exactly is the EU supposed to do to achieve compliance? And which effects does exactly Boeing need to remove? The only adverse effects that the US demonstrated before the Arbitrator were the 47 units of lost sales. So even if one assumes that, because of the subsidies paid, adverse effects on Boeing continue to linger in the marketplace, no demonstration of effects other than the lost sales for 47 planes was ever provided during the arbitration process. The deafening silence over this key issue leaves the EU in a rather impossible situation.

\subsection{Did the Arbitrator Respect its Mandate?}

The Arbitrator has violated its mandate by

- Disrespecting Article 22.4 of DSU (since the awarded retaliation rights overshoot the damage inflicted);

- Recommending an unworkable remedy (since the EU can never comply); and

- Undoing the balance of rights and obligations (Article 3.2), by disrespecting Article 22.4.

\subsection{How Should Adverse Effects have been Calculated?}

Given that the Arbitrator's mandate was to assess the damage suffered under the specified period, the award to Boeing should at best have been capped at $\$ 7,496.623 .000$. This is the damage that Boeing (and therefore the US), if at all (that is, assuming the LA/MSF for A350XWB had properly been before the Arbitrator) demonstrated that it suffered. When the EU had suffered a damage equivalent to this sum, that is, after one year of retaliation, retaliation must stop. A second year of retaliation overshoots the damage inflicted.

The US might, in principle, have suffered more but the US neither argued for this position nor demonstrated it. The Arbitrator is required to observe the US request, and not substitute its own judgment. It is conceivable that the Arbitrator projected into the future to assess the damages Boeing is likely to suffer in coming years but that would be inconsistent with his responsibility in this case and the principles governing retaliation awards in the WTO. In Mavroidis and Saggi (2020), we further assess the issue of how damages awarded might be calculated in those cases in which the effects of a disputed measure extend well into the future, potentially with no end in sight. 


\subsection{An Important Procedural Aspect: Improper Sequencing}

Recall, the United States won the right to retaliate before the Arbitrator had found that the European Union had not implemented the original panel's findings. This is fundamentally inconsistent with WTO law and it contravenes the foundation of the DSU, which establishes the sequential nature of compliance proceedings and request for authorization to retaliate. Furthermore, the two parties had signed an agreement to observe sequencing. ${ }^{18}$ Surprisingly, the Arbitrator did not even ask the question if it covered only one or more Article 21.5 of DSU proceedings. Even more surprisingly, in $\S \S 2.22-23$, the Arbitrator, invented a new term, "pre-authorization", to justify its decision for dis-observing sequencing. The DSU does not know of anything like this, of course. There is nothing like "pre-authorization". There is only authorization to retaliate when faced with non-compliance.

\section{No Trial and Error, Just Comedy of Errors}

We have argued above that the Arbitrator's decision and the report laying out the rationale for it suffer from several major shortcomings. There is a long line of Article 22.6 awards, which the Arbitrator here decided to neglect. Both the EU and Canada criticized forcefully the award. At the moment of writing, the counter-arbitration proceeding, the arbitration challenging the level of suspension proposed by the EU against subsidies received by Boeing (United States - Large Civil Aircraft (Second Complaint), WTO Doc. WT/DS/353/33) has reconvened its work. The uncertainty about the AB risks offering the European Union a Pyrrhic victory only (assuming it prevails).

The Airbus/Boeing dispute raises important issues, predominantly economic, and some legal as well.

It seems to us that it is virtually impossible for the EU to comply with the Arbitrator's ruling. In our companion piece [Mavroidis and Saggi (2021)], we further develop this argument, asking the more general question what is, both from a positive- as well as a normative perspective, the role of retaliation.

This case also raises larger questions about the structure of remedies in the WTO. Are the remedies as currently structured efficient? Schelling (1960) established that the credibility of threat, unlike that of promise, depends on its non-execution. In an empirical study, Bagwell et al. (2005) found no evidence to the opposite. Given that, should we constrain cross-retaliation, if our objective is to obtain compliance? ${ }^{19}$ More generally, does it make sense to constrain punishment if the primary objective is to induce compliance? And how can one square this type of analysis, with Ethier's (2006) insight that, because of uncertainty, the common incentive of the membership is not to sanction punishment but rather to constrain it?

There are also a number of institutional practices that deserve further scrutiny and discussion. Should the original panel members be allowed to serve as Arbitrators under Article 22.6? Should Arbitrators' reports remain un-appealed? Does it make any sense to compartmentalize the compliance and retaliation stages? Should not we think what kind of expertise is required for arbitral awards like this one to make (economic) sense?

18 WTO Doc. WT/DS316/21 of January 17, 2012.

19 The hostility of developed nations to cross-retaliation is well-documented. Robert Zoellick, then USTR (United States Trade Representative) and about to face cross-retaliation from Brazil in the US-Upland Cotton case has been quoted stating: "There's always a danger in trade relations - these things start to slip out of control. You know, keep in mind, Brazil sells about two and a half million dollars under a special preference program to the United States, under the GSP. We have been working with Brazil because of the problems of intellectual property violations here, which could lead to their removal. It did in the case of Ukraine. So, I think it is dangerous for people to go down these paths because one retaliates, and all of the sudden you might find out that something else happens. We have felt-in the case of intellectual property rights - that Brazil is trying. We've decided to give time to work, to try. But, one decides to retaliate, well, who knows, maybe others will too." (Transcript of Joint Press Availability, Deputy Secretary of State, Robert B. Zoellick, and Brazilian Finance Minister Antonio Palocci, Ministry of Finance, Brasilia, Brazil, October 6, 2005). 
To be sure, we are not the first to be thinking about the shortcomings of the WTO's enforcement mechanism. Many, and most notably, Bown and Ruta (2010) have adequately explained the shortcomings of the dispute settlement regime. In Mavroidis and Saggi (2021), we add our perspective to these concerns and argue that it is high time that the WTO membership thought seriously about the purpose and design of its dispute settlement process. There is a rich body of case law and economic research that can help guide future reforms.

\section{Instead of Conclusions: A Possible Rationale for the Decision}

We have argued above, that the Arbitrator awarded Boeing an ongoing right to retaliate (which could, potentially, last forever). Is there any way to make sense of the apparent lack of proportionality displayed in this decision?

Some insight into the outcome of the dispute can be obtained by entertaining the following set of counterfactual questions? What if Boeing had argued that its damage from Airbus launch aid, had not been limited to sales of 47 planes but rather that, absent subsidies, Airbus would simply not have entered the market, in which case, Boeing would have continued to operate as monopolist? Thus, had Boeing proven this claim, it would be entitled to all damage it had suffered as a result of the entry of Airbus into the market, and would continue to suffer in future years.

A few questions arise, and we will take them in turn:

- Would a claim to this effect be consistent with the concept of nullification and impairment, the legal basis for claiming damage in the WTO? (legal basis)

- What would be the evidentiary basis to prove such a claim? (evidentiary basis)

- How should the burden of proof be allocated across the disputing parties? (burden of proof)

- How would/should the damage be calculated? (calculation of damage)

Before we take this any further, we need to underscore that, instead of focusing on the 47 planes not sold, the US would have needed to argue that its damage was the loss of monopoly position already before the original panel. In fact, the only question from the four questions above, the US could have raised before the Arbitrator is the fourth question. We will assume thus, that the US had actually argued in the way described above from the outset.

\subsection{Legal Basis}

The US should have invoked Article 5(b) of the SCM Agreement. This provision makes it clear that nullification and impairment is used in the SCM Agreement as in the GATT-context. It is standing case law, that GATT practice is part of the GATT acquis. This term covers the legitimate expectations of WTO members to see that relevant prior case law, even in the absence of stare decisis in the WTO legal order, will be duly taken into account in future disputes, to the extent, of course, that it is relevant ( $\mathrm{AB}$ report on Japan-Alcoholic Beverages II, §§108-109).

GATT practice in this area is limited to one case. The Netherlands was facing restrictions in the US market, and could not export its dairy products anymore. It requested and obtained authorization to limit imports from the US, in retaliation. The rationale for the authorization, was, in the words of the GATT CONTRACTING PARTIES, that: ${ }^{20}$

... having regard

(i) to consideration of the value of the trade involved,

(ii) to the broader elements in the impairment suffered by the Netherlands,

20 GATT Doc. L/61, November 7, 1952. 
(iii) to the statement of the Netherlands Government that its principal objective in proposing the measure in question is to contribute to the eventual solution of the matter in accordance with the objectives and spirit of the General Agreement ... (emphasis added).

The only GATT case thus (since, for the rest, retaliation had consistently been unilateral and unauthorized), suggests that the level of retaliation would be calculated, using both the trade involved, as well as broader elements in the impairment -- a term that leaves ample room for US to have argued the position suggested above.

\subsection{Evidentiary Basis}

The US would have needed to show that, in the absence of launch aid, Airbus could not have entered the market. But here there is an issue of timing, since the SCM Agreement applies as of January 1, 1995. Existing subsidy programs should have been notified and brought into consistency within the first three years counting from the advent of the WTO (Article $28 \mathrm{SCM}$ ).

The US should have argued that the EU had not complied with its obligations under Article 28 of the SCM. This is the key, the quintessential element in the US complaint. Boeing lost its monopoly position because of subsidies paid already in the seventies and the eighties, and not because of the more recent subsidies. In fact, technology effects suggest that the new Airbus models benefitted from subsidies granted to prior models.

\subsection{Burden of Proof}

The burden of proof would naturally lie with the US.

\subsection{Quantifying the Damage}

The US would be asked to estimate the following:

- The size of Boeing's market in the absence of Airbus, and

- The prices that Boeing would have charged as a monopolist.

The damage suffered by Boeing would then be calculated by estimating the profits it would have earned as a monopolist, and comparing them to what it had actually earned when competing with Airbus. The difference between its profits under the two scenarios, would capture the damage suffered by Boeing due to the loss of its monopoly status. If the loss of monopoly status was permanent, the damage suffered would necessarily be ongoing and this could potentially justify an annual award like the one granted by the Arbitrator.

\subsection{A Final Point}

We understand, of course, that what we propose above is now impossible because of the manner in which the US chose to argue its case. In this Section, we have simply attempted to come up with a possible legal and economic rationale for the award granted by the Arbitrator. 


\section{References}

Anderson, Kym. 2002. Peculiarities of Retaliation in WTO Dispute Settlement, World Trade Review, 1: $123-134$.

Bagwell, Kyle W., Petros C. Mavroidis, and Robert W. Staiger. 2005. The Case for Tradable Remedies in WTO Dispute Settlement System, pp. 395 - 414 in Simon J. Evenett and Bernard Hoekman (eds.), Economic Development \& Multilateral Trade Cooperation, Palgrave McMillan \& The World Bank : Washington D.C.

Balistreri, Edward, Mavroidis, Petros C., and Thomas J. Prusa. 2020. What if? Tinkering with the Counterfactual, A Comment on US-Washing Machines (Article 22.6-US), EUI Working Paper Series RSCAS 2020/40: Florence, Italy.

Bown, Chad P., \& Rachel Brewster. 2017. US-COOL Retaliation: The WTO's Article 22.6 Arbitration, World Trade Review, 16: 371-394.

Bown, Chad P., \& Michele Ruta. 2010. The Economics of Permissible WTO Retaliation, pp. 149-193 in Chad P. Bown, and Joost H.B. Pauwelyn (eds.), The Law, Economics and Politics of Retaliation in WTO Dispute Settlement, Cambridge University Press: Cambridge, United Kingdom.

Brander, James, and Barbara Spencer. 1985. Export Subsidies and International Market Share Rivalry, Journal of International Economics, 18: 83-100.

Ethier, Wilfried J. 2006. Punishments and Dispute Settlement in Trade Agreements, The Equivalent Withdrawal of Concessions, Keio Economic Studies, 42: 1-23.

Feenstra, Robert C. 1998. Integration of Trade and Disintegration of Production in the Global Economy, Journal of Economic Perspectives, 12: 31-50.

Grossman, Gene M., and Petros C. Mavroidis. 2007. Would've or Should've? Impaired Benefits Due to Copyright Infringement, US-Section 110 (5), pp. 294-314 in Henrik Horn and Petros C. Mavroidis (eds.), The WTO Case Law, The American Law Institute Reporters' Studies, Cambridge University Press: Cambridge, United Kingdom.

Grossman, Gene M., and Petros C. Mavroidis. 2007a. Recurring Misunderstanding of Non-Recurring Subsidies, US-Certain EC Products, pp. 381-390 in Henrik Horn and Petros C. Mavroidis (eds.), The WTO Case Law, The American Law Institute Reporters' Studies, Cambridge University Press: Cambridge, United Kingdom.

Hahn, Michael, and Kirtikumar Mehta. 2013. It's a Bird, It's a Plane: Some Remarks on the Airbus Appellate Body Report (EC and Certain Member States - Large Civil Aircraft, WT/DS316/AB/R), World Trade Review, 12: 139-161.

Irwin, Douglas A. and Nina Pavcnik. 2004. Airbus Versus Boeing Revisited: International Competition In The Aircraft Market, Journal of International Economics, 64: 223-245.

Krugman, Paul. 1995. Peddling Prosperity: Economic Sense and Nonsense in the Age of Diminished Expectations, W.W. Norton \& Company: New York City, New York.

Limão, Nuno, and Saggi, Kamal. 2008. Tariff Retaliation Versus Financial Compensation in the Enforcement of International Trade Agreements, Journal of International Economics, 76: 48-60.

Mavroidis, Petros C. 2016. Mind Over Matter, pp. 333-378 in Kyle Bagwell and Robert W. Staiger (eds.), Handbook on Commercial Policy, Handbooks in Economics, Elsevier: Amsterdam and New York City.

Mavroidis, Petros C., and Kamal Saggi. 2021. The Law and Economics of WTO Dispute Settlement Re-visited. Mimeo. 
Mavroidis, Petros C., and Kamal Saggi. 2014. What is not so Cool about US-COOL Regulations? A Critical Analysis of the Appellate Body's Ruling on US-COOL, World Trade Review, 13: 1-22.

Schelling, Thomas. 1960. The Strategy of Conflict, Harvard University Press: Cambridge, Massachusetts. 


\section{Author contacts:}

\section{Petros C. Mavroidis}

Columbia Law School

Edwin B. Parker Professor of Law at Columbia Law School

Jerome Greene Hall, Room 734

435 West 116th Street

New York, NY 10027

Email: pmavro@law.columbia.edu

\section{Kamal Saggi}

Vanderbilt University

Frances and John Downing Family Professor of Economics

Department of Economics

PMB 351828

2301 Vanderbilt Place

Nashville, TN 37235

USA

Email: k.saggi@vanderbilt.edu 
With the support of the The European Commission supports the EUI through the European Union budget. This Erasmus+ Programme publication reflects the views only of the author(s), and the Commission cannot be held of the European Union responsible for any use which may be made of the information contained therein. 